\title{
Cytotoxic activity of NN-32 toxin from Indian spectacled cobra venom on human breast cancer cell lines
}

\author{
Saurabh S. Attarde and Sangeeta V. Pandit
}

\begin{abstract}
Background: Breast cancer is the most common cancer which causes significant morbidity and mortality among women worldwide. Lack of medical facilities for early detection, therapeutic strategies for treatment and side effects due to pharmacological compounds have encompassed the need for new therapies mostly from natural sources. A lot of components have been identified from different snake venoms as therapeutic agents. A group of polypeptides (60-70 amino acid residues) called cytotoxins or cardiotoxins present in an elapid family of snakes have a wide variety of pharmaceutical actions and have the tendency to damage a wide variety of cells including cancerous cells. The aim of the present study was to evaluate the cytotoxic effect of NN-32 protein toxin purified from Indian Spectacled Cobra venom against human breast cancer cell lines (MCF-7 and MDA-MB-231).
\end{abstract}

Methods: The NN-32 toxin was purified by ion exchange chromatography and further by RP-HPLC. The potential anticancer effects of the NN-32 toxin on MCF-7 and MDA-MB-231 cells were evaluated using MTT, anti-proliferation, neutral red (NR) uptake and Lactate Dehydrogenase (LDH) release assay.

Results: The ion exchange chromatography showed various peaks among fraction no. 35 showing cytotoxic activity and this fraction showed a single peak with retention time 3.6 mins by HPLC using C18 column. The NN-32 toxin induced cytotoxicity in MCF-7 and MDA-MB-231 cells with the $\mathrm{IC}_{50}$ value of 2.5 and $6.7 \mu \mathrm{g} / \mathrm{ml}$ respectively. The NN-32 showed significant cytotoxicity to both the cell lines along with low cytotoxicity to MCF-10A (normal breast epithelial) cells. The cytotoxic effect was further confirmed by the anti-proliferative, NR uptake and LDH release assays.

Conclusion: The purified toxin NN-32 from Naja naja venom showed cytotoxic activity against MCF-7 (ER+) and MDA-MB-231(ER-) cells in both dose dependent and time dependent manner.

Keywords: NN-32, Naja naja, Cytotoxity, MCF-7, MDA-MB-231, Breast cancer

\section{Background}

Breast cancer is the most common cancer which causes significant morbidity and mortality among women worldwide [1]. In India, over 80,000 new cases of breast cancer diagnosed and metastasis is one of the leading cause of death [2]. In recent years, due to lack of medical facilities for early detection, therapeutic strategies for treatment and side effects due to pharmacological compounds have encompassed the need for new therapies mostly from natural sources for long-term cancer prevention and treatment [3-5].

\footnotetext{
* Correspondence: drpanditsv@unipune.ac.in

Department of Zoology, Savitribai Phule Pune University, Ganeshkhind, Pune, Maharashtra 411007, India
}

Snake venom is a rich source of many proteins, peptides, macromolecules and many cytotoxins, neurotoxins, cardiotoxins, myotoxins, dendrotoxins, haemotoxins, fibrinolytic enzymes, Phospholipase A2 etc. [6]. Calmette et al. [7] in 1933 first reported that snake venom has anticancer activity and thereafter a lot of components from different snake venoms have been identified as showing therapeutic properties. A group of polypeptides (60-70 amino acid residues) called cytotoxins or cardiotoxins present in an elapid family of snakes have a wide variety of pharmaceutical actions and have the tendency to damage a wide variety of cells including cancerous cells $[8,9]$.

A number of compounds from venomous animals, such as snakes, scorpions, spiders, toads, frogs, bees, 
caterpillars, insects, wasps, centipedes and ants have been isolated and showed therapeutic applications [10-13]. For example, a compound TM601, modified form of the peptide Chlorotoxin (CTX) purified from Leiurus quinquestriatus scorpion venom, has been shown to block chloride channel specifically on glioma cell surface and also shown potent pleiotropic anti-angiogenic effect, which is currently under phase-II clinical trials $[14,15]$.

$\mathrm{NN}-32$ is a $6.7 \mathrm{KDa}$ proteinous toxin isolated from Indian spectacled cobra venom, which showed antioxidant and antitumor properties against EAC bearing BALB/c mice [16]. The present study reports the cytotoxic activity of a toxin NN-32 present in Naja naja venom against human breast cancer cell lines.

\section{Methods}

\section{Chemicals}

Carboxymethyl cellulose (CM Cellulose), Dulbecco's modified eagle medium (DMEM), Fetal bovine serum (FBS), Penicillin, Streptomycin and Trypsin-EDTA Solution were purchased from Himedia (India). Thiazolyl Blue Tetrazolium Bromide (MTT), Dimethyl Sulfoxide (DMSO), Neural Red (NR), Formaldehyde, $\beta$-Nicotinamide adenine dinucleotide reduced dipotassium salt $(\beta-\mathrm{NADH})$, Trypan Blue and Triton X-100 dye solution were purchased from Sigma-Aldrich (USA).

\section{Snake venom collection and ethics approval}

Lyophilized Naja naja [17] venom was purchased from Calcutta Snake Park, Kolkata, India and stored at $4{ }^{\circ} \mathrm{C}$ till further use. Venom concentration was expressed in terms of dry weight/protein equivalent. The study protocol was approved by the Institutional Biosafety Committee (IBSC) of Savitribai Phule Pune University, Pune, India.

\section{Purification of NN-32}

A $250 \mathrm{mg}$ of Lyophilized whole venom of Naja naja was dissolved in $5 \mathrm{ml}$ of de-ionized water and given a heat treatment for $30 \mathrm{~min}$ at $60^{\circ} \mathrm{C}$ in a water bath followed by centrifugation at $2500 \mathrm{rpm}$ for $20 \mathrm{~min} .50 \mathrm{mg}$ of the supernatant was loaded onto a CM-cellulose column $(100 \times 20 \mathrm{~mm})$ which was equilibrated with $0.02 \mathrm{M}$ phosphate buffer ( $\mathrm{pH} 7.2$ ). A total of 42 fractions (each of $5 \mathrm{ml}$ volume) were collected using the stepwise gradient of sodium chloride $(0.02 \mathrm{M}-1 \mathrm{M}$ in phosphate buffer, $\mathrm{pH} 7.2$ ) with a constant elution rate of $30 \mathrm{ml} / \mathrm{min}$ at room temperature. Protein content in the fractions was estimated by Lawry's method [18]. All the fractions were checked for their cytotoxic activity against MCF-7 cells. The fraction which was showing cytotoxic activity was further purified by Reverse phase HPLC (Shimadzu LC2010HT, Japan) using C18 column $(4.6 \times 250 \mathrm{~mm})$
(Waters, USA) equilibrated with $0.1 \%$ Trifluoroacetic acid (TFA) in water and eluted with a linear gradient of $100 \%$ acetonitrile in $0.1 \%$ TFA at a flow rate of $1 \mathrm{ml} /$ min. The HPLC profile of the fraction was monitored at $280 \mathrm{~nm}$ for $60 \mathrm{~min}$ using Shimadzu Prominence UV/Vis detector (SPD-20A).

\section{Characterization of $\mathrm{NN}-32$}

MALDI-MS (Applied Biosystems, 4700 Proteomics Analyzer 170) was performed to determine the mass of the fraction protein. Mass spectrometric spectra were obtained using MALDI-TOF system. MS/MS spectra were searched using the Mascot database search engine against the NCBInr protein database.

\section{Cell culture}

Human Breast cancer cell lines (MCF-7 and MDA-MB231) along with Human normal breast epithelial cell line (MCF-10A) were purchased from National Facility for Animal Tissue and Cell Culture, Pune, India. They were cultured in DMEM supplemented with $10 \%$ heatinactivated FBS, penicillin (100 units $/ \mathrm{ml})$ and streptomycin $(10 \mathrm{mg} / \mathrm{ml})$. Cells were grown to sub confluence at $37{ }^{\circ} \mathrm{C}$ in a humidified atmosphere of $5 \% \mathrm{CO}_{2}$.

\section{MTT assay}

MCF-7, MDA-MB-231 and MCF-10A cells were seeded at densities of $1 \times 10^{4}$ /well into 96 -well plates and incubated at $37{ }^{\circ} \mathrm{C}$ for $24 \mathrm{~h}$ under $5 \% \mathrm{CO}_{2}$. The cells were then treated with different concentrations of NN-32 (0.125$16 \mu \mathrm{g} / \mathrm{ml})$ and doxorubicin $(0.5-5 \mu \mathrm{M})$ as the positive control. After $48 \mathrm{~h}$ of incubation, $20 \mu \mathrm{l}$ of MTT solution $(5 \mathrm{mg} / \mathrm{ml}$ ) was added into each well and incubated for $4 \mathrm{~h}$. The medium was discarded and the formazan precipitate was dissolved in DMSO. The absorbance of the mixtures was determined using a microtiter plate reader at $570 \mathrm{~nm}$ and the cell viability expressed as percentage inhibition relative to controls. All experiments were performed in triplicates. The $\mathrm{IC}_{50}$ was generated for each cell line from the dose response curve.

\section{Anti-proliferation assay}

MCF-7 and MDA-MB-231 cells were seeded at densities of $1 \times 10^{4}$ cells/well into 6 -well plates and allowed to incubate for cell attachment for $24 \mathrm{~h}$. These cells were then exposed to 5, 10 and $15 \mu \mathrm{g} / \mathrm{ml}$ concentrations of NN-32 and the plates incubated at $37{ }^{\circ} \mathrm{C}$ under $5 \% \mathrm{CO}_{2}$, for 24,48 , and $72 \mathrm{~h}$. At the end of the incubation periods, the medium was removed and washed with cold PBS followed by the addition of $1 \mathrm{ml}$ of $0.05 \%$ trypsinEDTA. The plates were then incubated for $15 \mathrm{~min}$ at $37{ }^{\circ} \mathrm{C}$ and after the majority of the cells had detached from the plate, they were harvested by spinning the suspension for $10 \mathrm{~min}$ at $1000 \mathrm{rpm}$ using Eppendorf 
Centrifuge $5810 \mathrm{R}$ (Hamburg, Germany) and the supernatant was discarded. $20 \mu \mathrm{l}$ of the cell pellet were re suspended in $20 \mu \mathrm{l}$ of $0.4 \%$ trypan blue solution. The dyeexcluding viable cells were counted microscopically using a haemocytometer and expressed as percent of control cells that were still viable.

\section{Neutral red uptake assay}

The cells were seeded in 96-well plates and incubated overnight under $5 \% \mathrm{CO}_{2}$ at $37{ }^{\circ} \mathrm{C}$ until they reached $60 \%$ confluence. The medium was then discarded and replaced with $200 \mu \mathrm{l}$ of fresh growth medium containing the same concentrations of the NN-32 as that used in the MTT assay. Untreated cells under the same conditions were used as controls. The plates were incubated at $37{ }^{\circ} \mathrm{C}$ for 24,48 and $72 \mathrm{~h}$ under $5 \% \mathrm{CO} 2$ and the cells were then washed three times with $200 \mu \mathrm{l}$ of PBS. The plates were further incubated at $25{ }^{\circ} \mathrm{C}$ for $3 \mathrm{~h}$ in medium containing $200 \mu \mathrm{l} \mathrm{NR}$ solutions, and the cells subsequently washed to remove the NR solution. Cells were then exposed to fixing solution consisting of $1 \% \mathrm{CaCl}_{2}$ and $0.5 \%$ formaldehyde in milli-Q water for 2 min followed by two washes with $1 \%$ acetic acid and $50 \%$ ethanol in milli-
Q water. The plates were incubated for $10 \mathrm{~min}$ and then read in a micro plate reader at $540 \mathrm{~nm}$ [19].

\section{Lactate dehydrogenase release assay}

The cells were seeded in 96-well plates in $100 \mu \mathrm{l}$ of media and then treated with different concentrations of NN-32 $(0.125-16 \mu \mathrm{g} / \mathrm{mL})$. The permeability of the cell membrane of MCF-7 and MDA-MB-231 cell lines after treatment with NN-32 was determined by LDH release assay [19].

\section{Statistical analysis}

For the number of experiments indicated, data are shown as mean \pm SD. The paired Student's $t$ test was performed to evaluate two independent groups of samples. In all analyses, $p<0.05$ was taken as statistically significant.

\section{Results}

\section{Purification of NN-32}

$50 \mathrm{mg}$ of venom applied on Ion exchange chromatography column $(100 \times 20 \mathrm{~mm})$ resolve into several peaks (Fig. 1a). Among all the fractions, fraction number 35 was eluted with $0.5 \mathrm{M} \mathrm{NaCl}$ showed
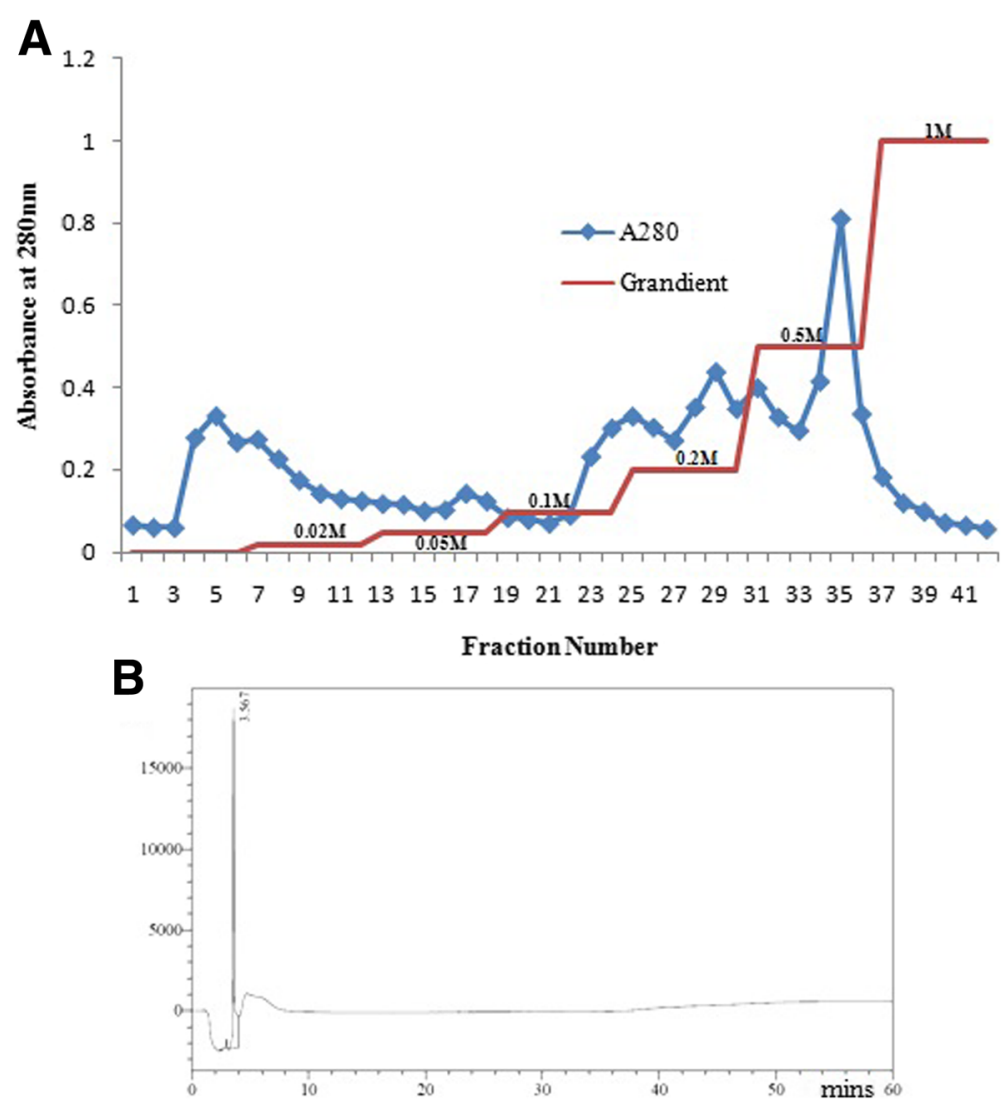

Fig. 1 a Purification of NN-32. An lon exchange chromatography of Indian spectacled cobra (Naja naja) venom. b Peak eluted with $0.5 \mathrm{M}$ NaCl solution was further purified by RP-HPLC. HPLC profile showed a single peak of NN-32 with a retention time of $3.6 \mathrm{~min}$ 
cytotoxicity against MCF-7 cell line. This fraction was further resolved through RP-HPLC using C18 column $(4.6 \times 250 \mathrm{~mm})$, produced a single peak with a retention time of 3.6 mins (Fig. 1b).

\section{Characterization of NN-32}

The molecular mass of NN-32 determined by MALDIMS was found to be $6.7 \mathrm{kDa}$ (Fig. 2). MS/MS spectra of NN-32 were searched against the NCBInr protein database using the Mascot database search engine showed the list of toxins having homology with NN-32 (Table 1).

\section{MTT assay}

Cytotoxic activity of NN-32 toxin was determined against two human breast cancer cell lines of which, one is estrogen receptor positive (ER+) MCF-7 cells and another is estrogen receptor negative (ER-) MDA-MB-231 cells. The percent inhibition of growth of these two breast cancer cells after treatment with the NN-32 toxin and Doxorubicin after $48 \mathrm{~h}$ was determined. The response of MCF-7 and MDA-MB-231 cells to increasing concentration of NN-32 toxin and Doxorubicin are shown in Figs. 3 and 4 respectively. The results showed the tendency of both cell lines to inhibit sharply upon treatment with low NN-32 and Doxorubicin concentrations, with narrowing response intensity as the concentration of NN-32 and Doxorubicin were increased. The $\mathrm{IC}_{50}$ values of Doxorubicin after $48 \mathrm{~h}$ of treatment was

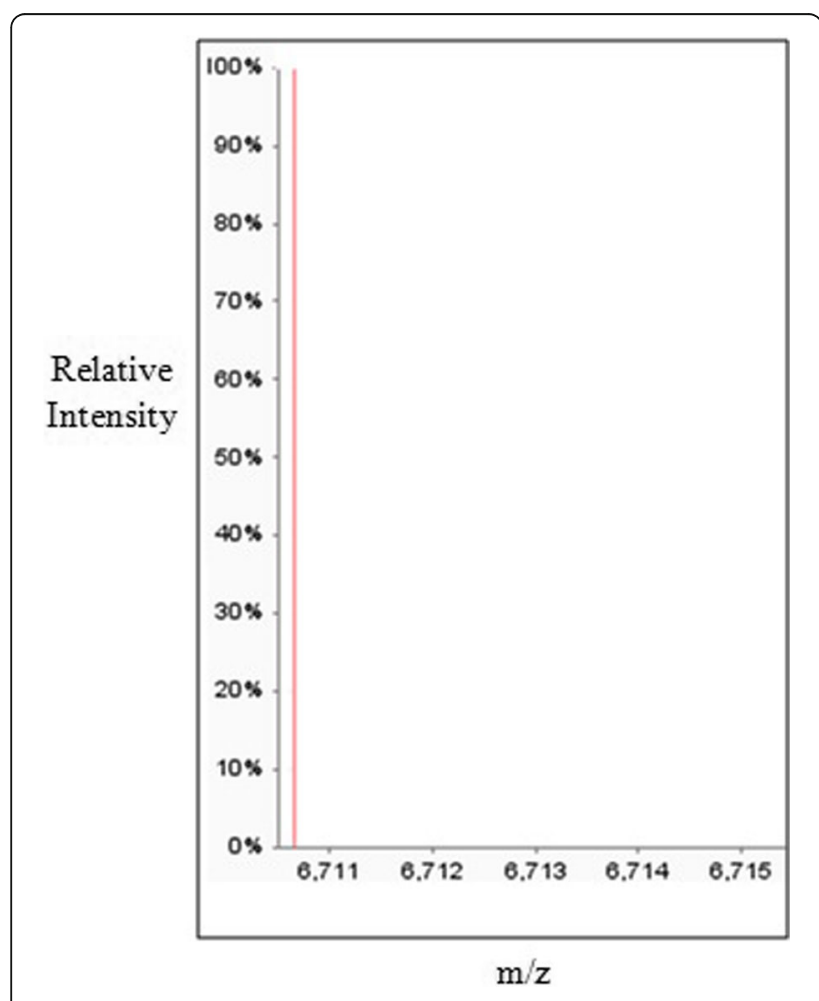

Fig. 2 MALDI-MS spectra of NN-32 showing a molecular mass of $6.7 \mathrm{kDa}$ found out to be $4.1 \mu \mathrm{M}$ and $15.1 \mu \mathrm{M}$ for MCF-7 and MDA-MB-231 cell lines, while $\mathrm{IC}_{50}$ values of $\mathrm{NN}-32$ toxin after $48 \mathrm{~h}$ treatment ranged between 2.5 and $6.7 \mu \mathrm{g} / \mathrm{ml}$ for MCF-7 and MDA-MB-231 cell lines respectively. The $\mathrm{IC}_{50}$ value of Doxorubicin and $\mathrm{NN}-32$ after $48 \mathrm{~h}$ of treatment was found out to be $39.6 \mu \mathrm{M}$ and $25 \mu \mathrm{g} / \mathrm{ml}$ respectively for the normal MCF-10A cells, is 10 times higher than that of the MCF-7 cells (Fig. 5). The NN-32 showed lower $\mathrm{IC}_{50}$ values for the cancer cells compared to the normal breast cells, suggesting that the toxin could have great potentials as an anticancer agent.

\section{Anti-proliferation assay}

The Anti-proliferative effects of the NN-32 toxin on MCF-7 and MDA-MB-231 cells were illustrated in Fig. 6. The percent survival of the MCF-7 cells after 24, 48 and $72 \mathrm{~h}$ of incubation with $10 \mu \mathrm{g} / \mathrm{ml}$ of NN-32 were 89,68 and 58\% respectively. However, MDA-MB-231 cells similarly treated with the NN-32 did not show much reduction in viability as the MCF-7 cells with values 87,83 and $64 \%$ respectively. This suggested that the NN-32 could have a greater effect on the viability of MCF-7 than MDA-MB-231 cells.

\section{NR uptake assay}

Neutral Red uptake assay was performed to determine the lysosomal activity of MCF-7 and MDA-MB-231 cells treated with the NN-32 toxin showed a significant decrease in lysosomal activity in a dose-dependent manner (Fig. 7). This NR uptake assay showed the lower sensitivity than that of MTT assay, this may be because of the lower number of lysosomes in the breast cancer cell lines. Neutral red is a positively charged dye that diffuses through the cellular membrane of viable cells and accumulates in the lysosomes, thus the intensity of its staining is directly proportional to a number of viable cells.

\section{$\mathrm{LDH}$ release assay}

LDH release in culture media is one of the indicators of cell death. Thus LDH release assay was performed to determine the cytotoxic activity of NN-32 toxin on human breast cancer cell lines. The LDH release curves of MCF-7 and MDA-MB-231 cell lines treated with different concentration of the NN-32 toxin showed that the cytotoxic effect of the NN-32 was concentration dependent (Fig. 8). The percent LDH release from MCF7 cell lines after $72 \mathrm{~h}$ exposure to $0.25,0.5,1$ and $2 \mu \mathrm{g} /$ $\mathrm{ml} \mathrm{NN}-32$ toxin were 52, 61, 67 and $74 \%$ respectively. This effect is greater than those observed for the same concentration of NN-32 on MDA-MB-231 cell lines with $36,46,59$ and $66 \%$ respectively after $72 \mathrm{~h}$. However, a higher concentration of $\mathrm{NN}-32$ toxin produced ever 
Table 1 List of toxins having homology with the NN-32 toxin, search carried out by mascot database search engine against the NCBInr protein database

\begin{tabular}{|c|c|c|c|}
\hline Sr. No & Protein ID & Protein Discription & MW. KDa \\
\hline 1 & 3SA2_NAJNA & Cytotoxin 2 OS-Naja naja PE $=1$ SV $=2$ & 6.75 \\
\hline 2 & 3SA2A_NAJNA & Cytotoxin 2a OS = Naja naja $\mathrm{PE}=1 \mathrm{SV}=2$ & 6.71 \\
\hline 3 & 3SA1_NAJKA & Cytotoxin 1 OS -Naja kaouthia PE $=1 \mathrm{SV}=1$ & 6.81 \\
\hline 4 & 3SA7A_NAJKA & Cytotoxin 2 OS -Naja kaouthia PE $=1$ SV $=1$ & 6.75 \\
\hline 5 & 3SA3 NAJNA & Cytotoxin 3 OS - Naja naja PE $=1$ SV $=1$ & 6.75 \\
\hline 6 & 3SA3_NAJKA & Cytotoxin $3 \mathrm{OS}=$ Naja kaouthia $\mathrm{PE}=1 \mathrm{SV}=1$ & 6.72 \\
\hline 7 & 3SA6_NAJSP & Cytotoxin 6 (Fragment) OS -Naja sputatrix PE $=3 \mathrm{SV}=1$ & 7.03 \\
\hline 8 & AOAOU5ARS4_NAJNA & Cytotoxin 11 (Fragment) OS = Naja naja GN $=\mathrm{CTX} 11 \mathrm{PE}=2 \mathrm{SV}=1$ & 7.96 \\
\hline 9 & AO AOU4N 5 W4_NAJN A & Cytotoxin 13 (Fragment) OS-Naja naja GN =CTX13 PE = 2 SV $=1$ & 7.95 \\
\hline 10 & 3SAO_NAJSP & Cytotoxin OS -Naja sputatrix PE $=3 \mathrm{SV}=1$ & 9.10 \\
\hline 11 & 3SA3_NAJAT & Cytotoxin $3 \mathrm{OS}=$ Naja atra PE $=1 \mathrm{SV}=1$ & 9.04 \\
\hline 12 & 3SA3_NAJSP & Cytotoxin $3 \mathrm{OS}=$ Naja sputatrix $\mathrm{PE}=1 \mathrm{SV}=1$ & 9.04 \\
\hline 13 & 3SA4_NAJKA & Cytotoxin 4 OS-Naja kaouthia PE $=1$ SV $=1$ & 9.04 \\
\hline 14 & 3SA3A_NAJAT & Cytotoxin $3 \mathrm{a} \mathrm{OS}=$ Naja atra $\mathrm{PE}=3 \mathrm{SV}=1$ & 9.07 \\
\hline 15 & 3SA3B_NAJAT & Cytotoxin 3b OS - Naja atra PE $=3 \mathrm{SV}=2$ & 9.02 \\
\hline 16 & 3SA1D_NAJAT & Cytotoxin Id/le OS = Naja atra PE $=3 \mathrm{SV}=1$ & 8.99 \\
\hline 17 & E2IU04_NAJAT & Three-finger toxin (Fragment) OS -Naja atra PE $=3 \mathrm{SV}=1$ & 6.97 \\
\hline 18 & Q9PS33_NAJOX & VC-I $=$ CYTOTOXIN OS $=$ Naja oxiatut PE $=3 \mathrm{SV}=1$ & 6.72 \\
\hline 19 & 3SAI_NAJOX & Cytotoxin 1 OS-Naja oxiatut PE $=1 \mathrm{SV}=1$ & 6.82 \\
\hline 20 & 3SA1_NAJAT & Cytotoxin 1 OS-Naja atra PE $=1 \mathrm{SV}=1$ & 8.99 \\
\hline 21 & 3SA8_NAJKA & Cytotoxin 1 OS-Naja kaouthia PE $=1 \mathrm{SV}=1$ & 6.70 \\
\hline 22 & 3SA1C NAJAT & Cytotoxin Ic OS-Naja atra PE $=3 \mathrm{SV}=1$ & 9.02 \\
\hline 23 & 3SAPF_NAJAT & Cytotoxin I-like P-15 OS = Naja atra PE $=3 \mathrm{SV}=1$ & 8.91 \\
\hline 24 & 3SATF_NAJAT & Cytotoxin I-like T-15 OS-Naja atra PE $=3 \mathrm{SV}=1$ & 9.00 \\
\hline 25 & 3SA1A_NAJAT & Cytotoxin la OS-Naja atra PE $=3 \mathrm{SV}=1$ & 8.98 \\
\hline 26 & 3SA1D_NAJAT & Isoform 2 of Cytotoxin Id/le OS-Naja atra & 10.77 \\
\hline 27 & 3SA8B_NAJAT & Cytotoxin 8 OS-Naja atra PE $=3 \mathrm{SV}=1$ & 8.90 \\
\hline 28 & 3SA3D_NAJAT & Cytotoxin 3d OS -Naja atra PE $=3 \mathrm{~S} \mathrm{~V}=1$ & 8.93 \\
\hline 29 & 3SAFA_NAJAT & Cytotoxin SP15a OS $=$ Naja atra $\mathrm{PE}=1 \mathrm{SV}=1$ & 6.68 \\
\hline 30 & E2ITZ7_NAJAT & Three-finger toxin OS - Naja atra PE $=3 \mathrm{SV}=1$ & 8.83 \\
\hline
\end{tabular}
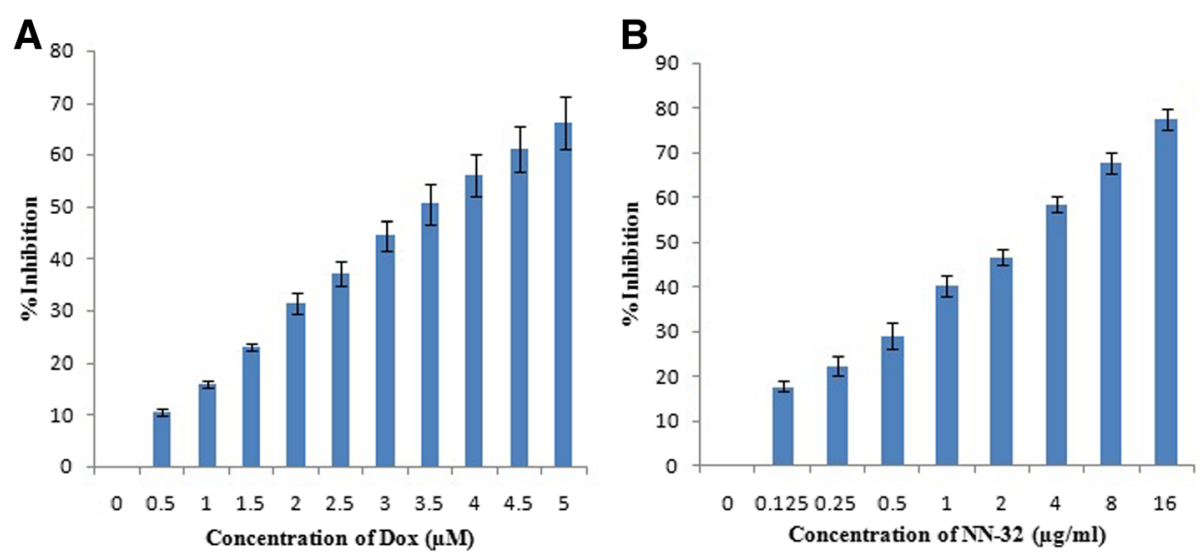

Fig. 3 Inhibition of MCF-7 cells after $48 \mathrm{~h}$ of treatment with (a) Doxorubicin and (b) NN-32 toxin. Values are expressed as mean \pm Std. Dev $(n=3)$ 

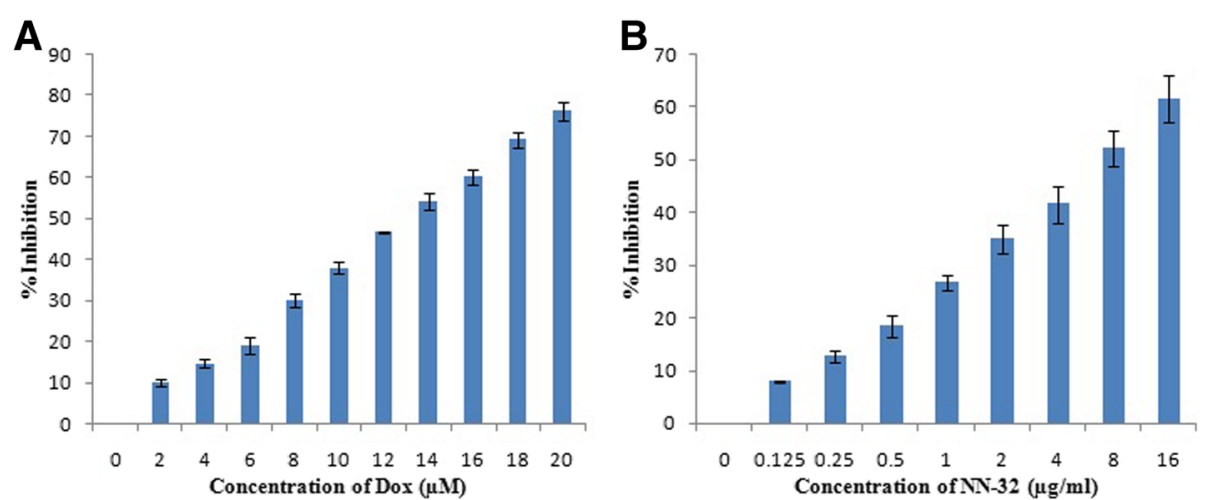

Fig. 4 Inhibition of MDA-MB-231 cells after $48 \mathrm{~h}$ of treatment with (a) Doxorubicin and (b) NN-32 toxin. Values are expressed as mean \pm Std. Dev $(n=3)$

higher LDH release in both MCF-7 and MDA-MB-231 cells.

\section{Discussion}

Since long, natural products from floral and faunal origin have been used for therapeutic purposes and around $87 \%$ of the human diseases are treated with these natural products and their related drugs [20].

Cardiotoxin-3 (CTX-3), a basic polypeptide of 60 amino acid residues from Naja naja atra venom induced apoptotic cell death accompanied by upgradation of both bax \& endonuclease $G$ and down regulation of bcl-x in K562 cells [21]. drCT-1 a heat stable, 7.2 kDa protein toxin from Indian Russell's viper venom is supposed to possess anti-proliferative, cytotoxic and apoptotic activity on EAC mice and human leukemic cells (U937/K562) [22].

Salmosin, a disintegrin isolated from Korean snake venom, efficiently suppressed the growth of the metastatic tumor as well as the solid tumor in mice. Also, LAAO isolated from Agkistrodon acutus snake venom arrest tumor cells at a sub-G1 phase of cell cycle and induced apoptosis via fas pathway in A549 cells [23].

Crototoxin 2, a disintegrin isolated from Crotalus atrox induced cancer cell migration and lung tumor colonization in BALB/c mice [24]. VRCTC-310 is a natural product by combining two purified snake venom, a three protein fraction from Crotalus durissus terrificus venom and Naja naja atra, exerted an inhibitory effect on human and murine cell lines. In a phase-I study, 15 patients with refractory malignancies were given intramuscular injection daily for 30 days continuously to evaluate the tolerated dose (MTD), safety profile and pharmaceutical data. MCD was found out to be $0.017 \mathrm{mg} / \mathrm{kg}$ and recommended for phase-II studies [25]. Cytotoxin-II isolated from Caspian cobra (Naja Naja oxiana) showed potent anticancer effects in a breast carcinoma cell line via induction of apoptosis through lysosomal damage, production of intracellular ROS, mitochondrial damage and activation of caspases [26].

The present study showed that NN-32 isolated from Naja naja (Indian spectacled cobra) venom showed significant cytotoxicity against MCF-7 and MDA-MB-231 in both dose and time dependent manner, and considerably less towards normal breast cells (MCF-10A). The molecular mass of NN-32 was $6.7 \mathrm{kDa}$ and N-terminal amino acid sequence for first 10 amino acid was LKCNKLVPLF [16].

MS/MS spectra of NN-32 searched against the NCBInr protein database using Mascot database search
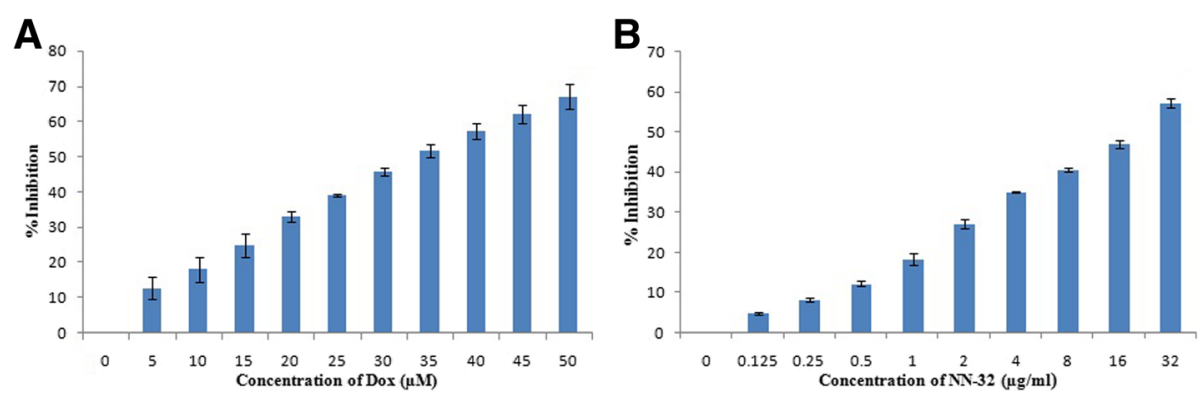

Fig. 5 Inhibition of MCF-10A cells after $48 \mathrm{~h}$ of treatment with (a) Doxorubicin and (b) NN-32 toxin. Values are expressed as mean \pm Std. $\operatorname{Dev}(n=3)$ 

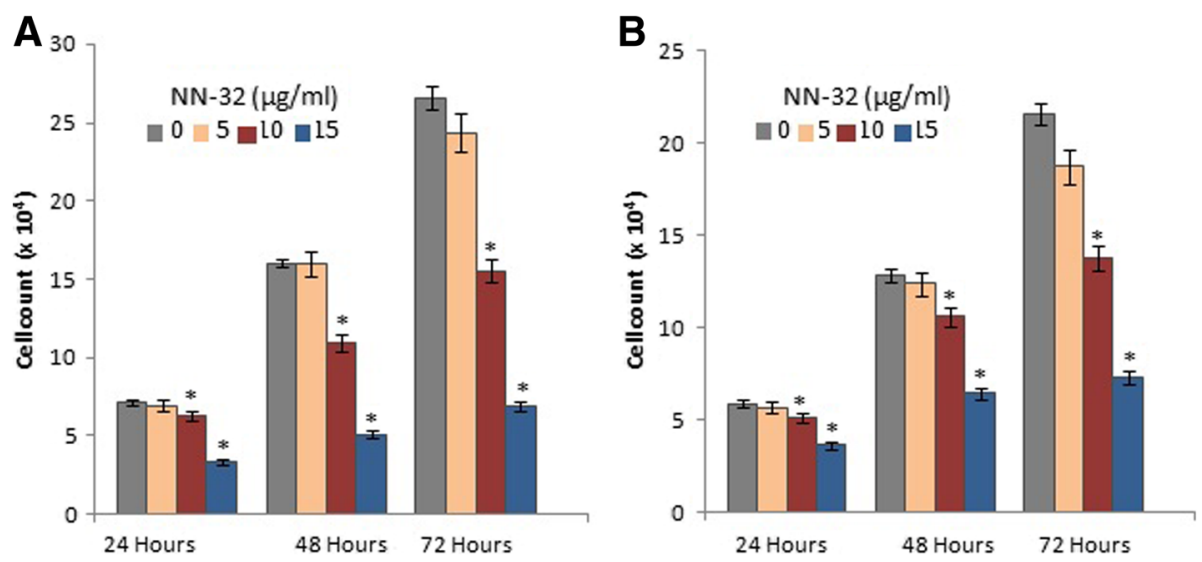

Fig. 6 Viability of Human breast cancer cells treated with NN-32 after 24, 48 and 72 h, (a) MCF-7 cell and (b) MDA-MB-231 cell. Values are expressed as mean $\pm \operatorname{Std}$. Dev $(n=3) .{ }^{*} p<0.05$ in comparison with the control group

engine showed homology with Cytotoxin 2 (accession no. P01440), Cytotoxin 2a (accession no. P86538), Cytotoxin 3 (accession no. P24780) from Naja naja; Cytotoxin 1 (accession no. P01447), Cytotoxin 2 (accession no. P01445), Cytotoxin 3 (accession no. P01446) from Naja kaouthia and Cytotoxin 6 (accession no. P073858) from Naja sputatrix.

NKCT1 is a protein toxin isolated from Naja Koauthia venom after conjugation with gold nanoparticle i.e. GNP-NKCT1 showed anticancer effect both in vivo and in-vitro in EAC cells. GNP-NKCT1 induced caspase dependent apoptosis pathway in EAC cells and induced the late apoptotic stage and arrested cell cycle division at G0/G1 stage [27].

NN-32 showed antitumor and antioxidant properties against EAC bearing BALB/c mice [16]. NN-32 also showed anticancer activity in human leukemic U937 cells by promoting apoptosis, arresting cell cycle, suppressing vascular endothelial growth factor and matrix metalloproteinase activities [28].
The major anticancer mechanism activated by snake venom toxins is by mitochondria-dependent cell death pathway. Taiwan cobra cardiotoxin-III induced apoptosis by loss of mitochondrial membrane potential, release of cytochrome c, activation of caspase 9 and caspase 3, and altered expression of Bcl-2 family proteins [29, 30].

NN-32 showed cytotoxicity on EAC cells and it upregulated expression of proapoptotic proteins $\mathrm{Bax}$ and downregulated antiapoptotic protein Bcl-2 expression [16]. Increase in Bax: $\mathrm{Bcl}-2$ ration results in series of events that lead to the conversion of procaspase 9 to active caspase 9 . Caspase 9 is an effective downstream molecule of the mitochondrial pathway of apoptosis and will lead to the conversion of active caspase 3 from procaspase 3 , which further trigger a cascade of intracellular events leading to programmed cell death [16]. Increase in expression of caspase 3 and caspase 9 in EAC cells after treatment suggested that NN-32 might have a role in the intrinsic pathway of apoptosis [16].
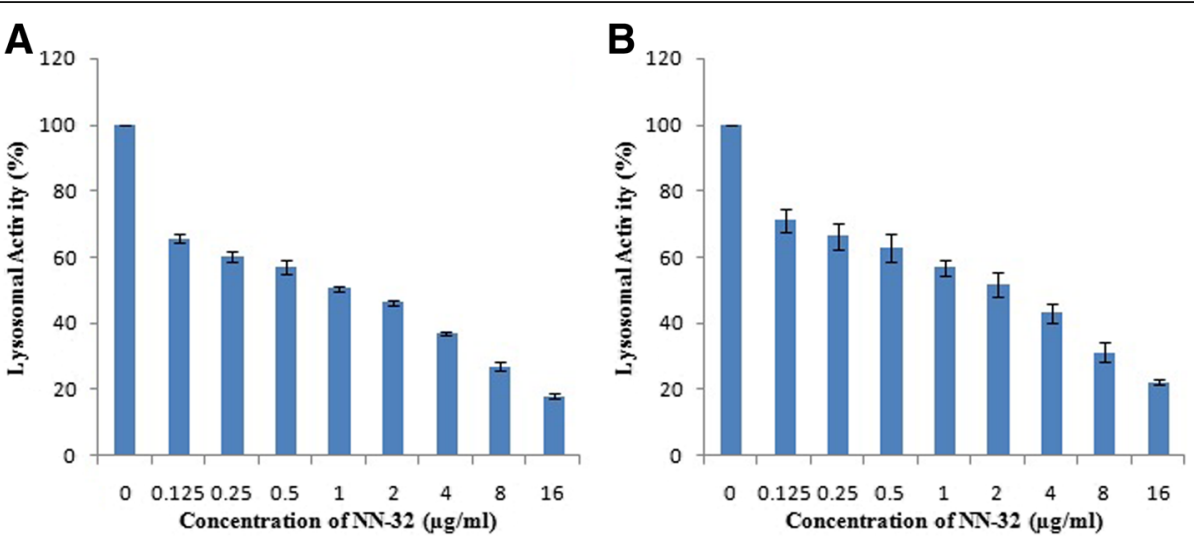

Fig. 7 Lysosomal activity of breast cancer cell lines treated with NN-32 toxin for $72 \mathrm{~h}$, determined by neural red uptake assay. a MCF-7 cell line and, (b) MDA-MB-231 cell line. Values are expressed as mean \pm Std. Dev $(n=3)$ 

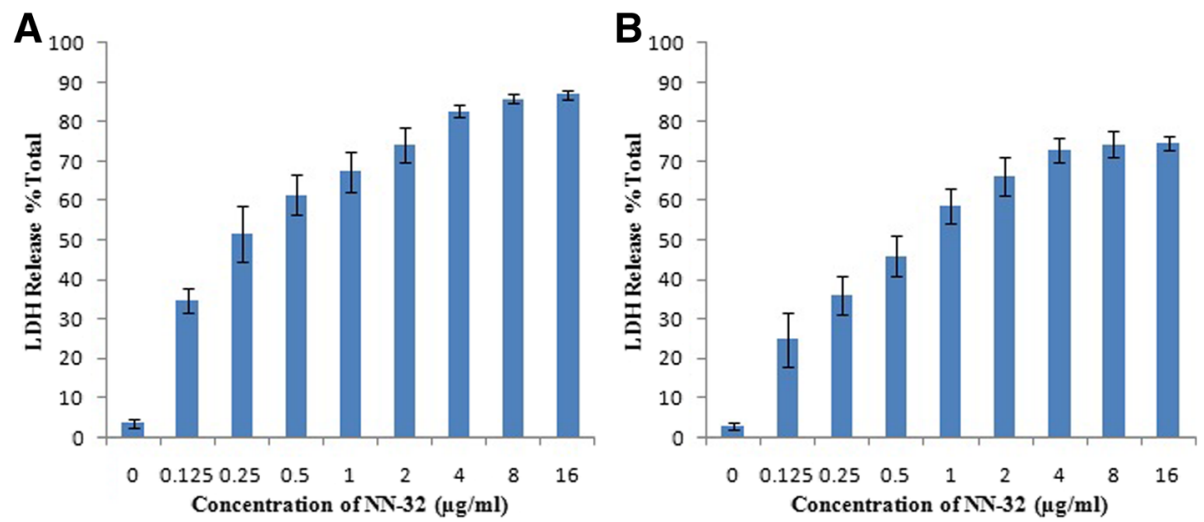

Fig. 8 Lactate Dehydrogenase (LDH) release from (a) MCF-7 cells and, (b) MDA-MB-231 cells treated with the NN-32 toxin. Values are expressed as mean \pm Std. Dev $(n=3)$

\section{Conclusion}

The MTT, Antiproliferation, Neural red uptake and $\mathrm{LDH}$ release assay used to evaluate the cytotoxicity of NN-32 toxin purified from Naja naja venom on MCF-7 and MDA-MB-231 cell lines showed that the protein toxin NN-32 is significantly cytotoxic to these cell lines in a both dose and time dependent manner, and considerably less towards normal breast cells (MCF-10A). This finding highlights the potential of $\mathrm{NN}-32$ toxin in the treatment of Breast cancer. However, detailed investigation of complete sequence, structure and molecular mechanism of action for this activity is required to potentiate the use this NN-32 toxin as a therapeutic agent for cancer treatment.

\section{Abbreviations}

DMEM: Dulbecco's modified eagle medium; DMSO: Dimethylsulphoxide; ER: Estrogen receptor negative; ER + : Estrogen receptor positive; FBS: Fetal bovine serum; $\mathrm{I}_{50}$ : Half maximal inhibitory concentration; LDH: Lactate dehydrogenase; MS: Mass spectrometry; MTT: 3-(4,5-dimethylthiazol-2-Yl)-2,5diphenyltetrazolium bromide; NR: Neutral red

\section{Acknowledgements}

We are grateful to Prof. Ameeta Ravikumar for valuable suggestions, Mr. Prashant Gaikwad for assistance in the purification of NN-32 and to the Head, Department of Zoology for providing laboratory facilities.

\section{Funding}

The authors are grateful to the 'University Grants Commission-Centre for Advanced Studies (CAS-Phase III)', 'Departmental Research and Developmental Program (DRDP)' and 'Department of Science \& Technology Promotion of University Research and Scientific Excellence' for the partial financial assistance.

\section{Availability of data and materials}

Data are all contained within the paper.

\section{Authors' contributions}

Conducting Experiments in Laboratory, Data collection, analysis, graphical representation and interpretation were done by SSA. Article was written by SSA and SVP. Conception, experiment design, overall monitoring and final approval of the article was done by SVP. All Authors read and approved the final manuscripts.
Ethics approval and consent to participate

The study protocol was approved by the Institutional Biosafety Committee (IBSC) of Savitribai Phule Pune University, Pune, India.

\section{Consent for publication}

We have the consent for this publication.

\section{Competing interests}

The authors declare that they have no competing interests.

\section{Publisher's Note}

Springer Nature remains neutral with regard to jurisdictional claims in published maps and institutional affiliations.

Received: 18 July 2017 Accepted: 19 November 2017

Published online: 28 November 2017

\section{References}

1. Ekmektzoglou KA, Xanthos T, German V, Zografos GC. Breast cancer: from the earliest times through to the end of the 20th century. Eur J Obstet Gynaecol Reprod Biol. 2009;145:3-8.

2. Mukherjee AK, Basu S, Sarkar N, Ghosh AC. Advances in cancer therapy with plant based natural products. Curr Med Chem. 2001;12:1467-86.

3. Ferguson PJ, Kurowska E, Freeman DJ, Chambers AF, Koropatnick DJ. A flavonoid fraction from cranberry extract inhibits proliferation of human tumor cell lines. J Nutr. 2004;134:1529-35.

4. Jo EH, Hong HD, Ahn NC, Jung JW, Yang SR, Park JS, Kim SH, Lee YS, Kang $\mathrm{KS}$. Modulations of the $\mathrm{BCl}-2 / \mathrm{Bax}$ family were involved in the chemopreventive effects of licorice root (Glycyrrhiza uralensis Fisch) in MCF-7 human breast cancer cell. J Agric Food Chem. 2004;52:1715-9.

5. Mukherjee AK, Basu S, Sarkar N, Ghosh AC. Advances in cancer therapy with plant based natural products. Curr Med Chem. 2001;8:1467-86.

6. Debnath A, Saha A, Gomes A, Biswas S, Chakrabarti P, Giri B, Biswas AK, Gupta SD, Gomes A. A lethal cardiotoxic-cytotoxic protein from the Indian monocellate cobra (Naja kaouthia) venom. Toxicon. 2010:56:569-79.

7. Calmette A, Saenz A, Costil L. Effets du venin de cobra sur les greffes cancereuses et sur le cancer spontane (adeno-carcinoma) de la souris. CR Acad Sci. 1933;197:205-9

8. Dufton MJ, Hider RC. Structure and pharmacology of elapid cytotoxins. Pharmacol Ther. 1988;36:1-40.

9. Feofanov AV, Sharonov GV, Astapovo MV, Radionov DI, Utkin YN, Arseniev AS. Cancer cell injury by cytotoxins from cobra venom is mediated through Iysosomal damage. Biochem J. 2005;390:11-8.

10. Lewis RJ, Garcia ML. Therapeutic potential of venom peptides. Nat Rev Drug Discov. 2003;2:790-802.

11. Fernandes-Pedrosa MF, Félix-Silva J, Menezes YA. Toxins from venomous animals: gene cloning, protein expression and biotechnological applications. 
An Integrated View of the Molecular Recognition and Toxinology: From Analytical Procedures to Biomedical Applications. 2013:23-71.

12. Warner RL, McClintock SD, Barron AG, de la Iglesia FA. Hemostatic properties of a venomic protein in rat organ trauma. Exp Mol Pathol. 2009:87:204-11.

13. Fenard D, Lambeau G, Valentin E, Lefebvre J, Lazdunski M, Doglio A. Secreted phospholipases A2, a new class of HIV inhibitors that block virus entry into host cells. J Clin Invest. 1999;104:611-8.

14. Fu Y, An N, Li K, Zheng Y, Liang A. Chlorotoxin-conjugated nanoparticles as potential glioma-targeted drugs. J Neuro-Oncol. 2012;107:457-62.

15. Jacoby DB, Dyskin E, Yalcin M, Kesavan K, Dahlberg W, Ratliff J, Johnson EW, Mousa SA. Potent pleiotropic anti-angiogenic effects of TM601, a synthetic chlorotoxin peptide. Anticancer Res. 2010;30:39-46.

16. Das T, Bhattacharya S, Halder B, Biswas A, Gupta SD, Gomes A, Gomes A. Cytotoxic and antioxidant property of a purified fraction (NN-32) of Indian Naja naja venom on Ehrlich ascites carcinoma in BALB/c mice. Toxicon. 2011;57:1065-72.

17. Stejneger L. Herpetology of Japan and adjacent territory. Bull. U.S. Nat. Hist. Mus. 2017;58:1-577.

18. Lowry OH, Rosebrough NJ, Farr AL, Randall RJ. Protein measurement with the Folin phenol reagent. J Biol Chem. 1951;193:265-75.

19. Abdullah AS, Mohammed AS, Abdullah R, Mirghani ME, Al-Qubaisi M. Cytotoxic effects of Mangifera indica L. kernel extract on human breast cancer (MCF-7 and MDA-MB-231 cell lines) and bioactive constituents in the crude extract. BMC Complement Altern Med. 2014;14:199.

20. Chin YW, Balunas MJ, Chai HB, Kinghorn AD. Drug discovery from natural sources. AAPS J. 2006;8:E239-59.

21. Yang SH, Chien CM, Lu MC, Lin YH, Hu XW, Lin SR. Up-regulation of Bax and endonuclease $\mathrm{G}$, and down-modulation of Bcl-XL involved in cardiotoxin IIIinduced apoptosis in K562 cells. Exp Mol Med. 2006;38:435-44.

22. Gomes A, Choudhury SR, Saha A, Mishra R, Giri B, Biswas AK, Debnath A, Gomes A. A heat stable protein toxin (drCT-I) from the Indian viper (Daboia russelli russelli) venom having antiproliferative, cytotoxic and apoptotic activities. Toxicon. 2007;49:46-56.

23. Kang IC, Lee YD, Kim DS. A novel disintegrin salmosin inhibits tumor angiogenesis. Cancer Res. 1999;59:3754-60.

24. Gomes A, Bhattacharjee P, Mishra R, Biswas AK, Dasgupta SC, Giri B, Debnath A, Gupta SD, Das T, Gomes A. Anticancer potential of animal venoms and toxins. Indian J Exp Biol. 2010;48:93-103.

25. Costa LA, Miles HA, Diez RA, Araujo CE, Molina CM, Cervellino JC. Phase study of VRCTC-310, a purified phospholipase A2 purified from snake venom, in patients with refractory cancer: safety and pharmacokinetic data. Anticancer. 1997;8:829-34.

26. Ebrahim K, Shirazi FH, Vatanpour H, Kobarfard F, Rabiei H. Anticancer activity of cobra venom polypeptide, cytotoxin-II, against human breast adenocarcinoma cell line (MCF-7) via the induction of apoptosis. J Breast Cancer. 2014;17:314-22.

27. Bhowmik T, Pratim Saha P, Kumar DasGupta A, Gomes A. Influence of gold nanoparticle tagged snake venom protein toxin NKCT1 on Ehrlich Ascites carcinoma (EAC) and EAC induced solid tumor bearing male albino mice. Curr Drug Deliv. 2014;11:652-64.

28. Das T, Bhattacharya S, Biswas A, Gupta SD, Gomes A, Gomes A. Inhibition of leukemic U937 cell growth by induction of apoptosis, cell cycle arrest and suppression of VEGF, MMP-2 and MMP-9 activities by cytotoxin protein NN-32 purified from Indian spectacled cobra (Naja naja) venom. Toxicon. 2013;65:1-4.

29. Chen XY, Yang HX, Qu SF, Liu J, Lv P, Xu JP, Xu KS. Involvement of p38 and c-Jun N-terminal protein kinase in cardiotoxin III-induced apoptosis of K562 cells. Biol Pharm Bull. 2009;32:583-8.

30. Lin KL, Su JC, Chien CM, Chuang PW, Chang LS, Lin SR. Down-regulation of the JAK2/PI3K-mediated signaling activation is involved in Taiwan cobra cardiotoxin III-induced apoptosis of human breast MDA-MB-231 cancer cells. Toxicon. 2010:55:1263-73.

\section{Submit your next manuscript to BioMed Central and we will help you at every step:}

- We accept pre-submission inquiries

- Our selector tool helps you to find the most relevant journal

- We provide round the clock customer support

- Convenient online submission

- Thorough peer review

- Inclusion in PubMed and all major indexing services

- Maximum visibility for your research

Submit your manuscript at www.biomedcentral.com/submit

Biomed Central 